\title{
Decreased erythrocyte catalase level in iron deficiency
}

Demir eksikliğinde eritrosit katalaz seviyesinin azalması

\author{
Şinasi Özsoylu
}

\section{To the Editor,}

Arslan et al.'s recent study provides an opportunity to discuss our earlier results from a 1964 study on early diagnosis only iron deficiency anemia and sideropenia [1,2]. Catalase is present in almost all cells, including red cells, and is known to be the most active enzyme involved in the destruction of hydrogen peroxide, which causes oxidative stress. In iron deficiency red cell catalase synthesis decreases before the hemoglobin level does. When its synthesis decreases in iron deficiency anemia and sideropenia, the level of oxidative stress-associated substances increases as a result. As such, the authors' statement, "increased oxidative stress may play a role in the pathogenesis of iron deficiency anemia" should be amended with, "as increased oxidative stress occurs as a result of iron deficiency".

\section{Conflict of interest statement}

The authors of this paper have no conflicts of interest, including specific financial interests, relationships, and/or affiliations relevant to the subject matter or materials included.

\section{References}

1. Arslan N, Horoz M, Çelik H. Evaluation of oxidative status in iron deficiency anemia through total antioxidant capacity using an automated method. Turk J Hematol 2011;28:42-46

2. Özsoylu Ş. Decreased activity of iron-containing enzyme catalase in human iron deficiency anemia. Turk $\mathrm{J}$ Pediatr 1964;6:200-210 